Article

\title{
Chromium Removal from Tannery Wastewater by Electrocoagulation: Optimization and Sludge Characterization
}

\author{
Nahid M. Genawi ${ }^{1}$, Mohamed H. Ibrahim ${ }^{2}$, Muftah H. El-Naas ${ }^{2, *(\mathbb{D})}$ and Awad E. Alshaik ${ }^{3}$ \\ 1 Department of Chemistry and Earth Science, Qatar University, Doha 2713, Qatar; nahidm.genawi@qu.edu.qa \\ Gas Processing Center, Qatar University, Doha 2713, Qatar; m.ibrahim@qu.edu.qa \\ 3 Sudan Academy of Science, Khartoum 999129, Sudan; awad.alshaik.sas@gmail.com \\ * Correspondence: muftah@qu.edu.qa
}

Received: 2 April 2020; Accepted: 1 May 2020; Published: 13 May 2020

check for updates

\begin{abstract}
The treatment of tannery effluent is of great interest as it contains a complex mixture of pollutants, primarily chromium. The disposal of this wastewater can have adverse effects on the environment and aquatic life, which is an emerging problem for the environment. In this work, electrocoagulation is used to remove chromium from real tannery wastewater, focusing on performance optimization and sludge characterization. Electrocoagulation experiments were conducted using an electrochemical cell with iron electrodes immersed in a specific volume of tannery wastewater. Operating parameters, such as the initial chromium concentration, $\mathrm{pH}$ and current density as well as power consumption were evaluated to determine optimum chromium removal. The optimization was performed using Response Surface Methodology combined with central composite design. Analysis of variance (ANOVA) was used to determine the response, residual, probability, 3D surface and contour plots. The maximum chromium removal was $100 \%$ at the optimum values of $13 \mathrm{~mA} / \mathrm{cm}^{2}, 7$ and $750 \mathrm{ppm}$ for current density, $\mathrm{pH}$ and concentration, respectively.
\end{abstract}

Keywords: electrocoagulation; chromium; power consumption; optimization; wastewater treatment

\section{Introduction}

Chromium has several oxidation states, and each state has its own unique set of properties. For example, the trivalent state of chromium ( $\mathrm{Cr}(\mathrm{III}))$ is essential for carbohydrate metabolism in humans [1]; on the other hand, hexavalent chromium $(\mathrm{Cr}(\mathrm{VI}))$ is considered to be toxic [2]. $\mathrm{Cr}(\mathrm{VI})$ is a hundred times more toxic than $\mathrm{Cr}(\mathrm{III})$, and it is also more water soluble $[3,4]$. The toxicological concern for $\mathrm{Cr}(\mathrm{VI})$ stems from the fact that it is a strong oxidizing agent that can release free radicals that can have carcinogenic effects on cells [3]. $\mathrm{Cr}(\mathrm{VI})$ rarely exists in nature as an element; it is usually coupled with other elements to form compounds such as iron(II) chromite $\left(\mathrm{FeCr}_{2} \mathrm{O}_{4}\right)$. Hereafter, $\mathrm{Cr}(\mathrm{VI})$ is mined from these compounds to be used. Hence, any occurrence or contamination of $\mathrm{Cr}(\mathrm{VI})$ in the environment is attributed to anthropogenic activities. Hexavalent chromium is used widely in different industries such as chrome plating, textiles and leather tanning. Tanning is a process of converting raw hides or skins into leather [5]. It utilizes a considerable amounts of tanning powder, which mainly consists of chromium sulfate $\left(\mathrm{Cr}_{2}(\mathrm{SO} 4)_{3}\right)$, which is produced by the reduction of $\mathrm{Cr}(\mathrm{VI})$ to $\mathrm{Cr}(\mathrm{III})$ using sulfur dioxide. Approximately $40 \%$ of the used chromium in the reduction process is disposed into the tanning process water [6]. The United States Environmental Protection Agency allows a maximum of $0.15 \mathrm{~g} / \mathrm{kg}$ of chromium to be released in the leather tanning industry's effluent [7]. Several techniques exist for chromium removal from wastewater including chemical precipitation, adsorption, ion exchange, membrane filtration, flotation, coagulation and electrocoagulation (EC) [8]. EC is one 
of the most used techniques to treat a wide variety of wastewaters. EC produces electrochemical coagulants that have the ability to remove a wide array of pollutants from wastewaters. A typical EC cell contains two electrodes (anode and cathode), which are connected externally by a power supply and submerged in a specific type of polluted water. Iron and aluminum electrodes are the most utilized electrodes for EC processes according to the literature [9]. EC possess several key features compared to other techniques including a low operating cost, high removal capacity and low sludge generation [10]. In addition, EC usually utilizes simple compact iron or aluminum electrodes to produce the coagulants, which further adds to its ease of operation. Additionally, the flocs formed by using aluminum and iron electrodes are relatively dense and can be dewatered easily. Hence, this facilitates sludge management when EC is used and makes it more attractive than other techniques [11,12]. The EC process is used for removing numerous pollutants from wastewater, such as chromium, dyes and organic contaminants in refinery effluents $[13,14]$. Several factors affect the removal of chromium when EC is used including $\mathrm{pH}$, current density (CD), electrode material and the initial concentration of chromium. Hamadan and El-Naas reported that the chromium removal from groundwater increased with an increase in the current density and achieved $100 \%$ removal at a CD of $7.9 \mathrm{~mA} / \mathrm{cm}^{2}$ [15]. An EC column system with a helical iron cathode wrapped around an anode rod was also evaluated for the continuous removal of chromium from groundwater [16]. The column was injected with air to facilitate the mixing and improve the EC performance. Cheballaha et al. achieved similar results at high current densities as well. In general, having more current density led to more electrode dissolution and, hence, an increase in the removal efficiency [17]. As for the $\mathrm{pH}$, different authors reported sufficient removal under alkaline and acidic conditions $[18,19]$. Treating tannery wastewater using EC can generate substantial amounts of sludge that contains chromium, which can be recycled back as a raw material for the tannery process.

In this work, the electrochemical removal of chromium from real tannery water using iron electrodes has been studied. The optimal removal conditions were also determined using Response Surface Methodology. To the best of the authors' knowledge, characterizing the sludge resulting from the EC process to evaluate its reuse potential as tannery raw material has not yet been addressed in the open literature.

\section{Electrocoagulation Mechanism}

The reactions taking place in EC cell when an iron electrode is used are summarized below [16]:

$$
\begin{aligned}
& \mathrm{Cr}_{2} \mathrm{O}^{2-}+14 \mathrm{H}^{+}+6 \mathrm{e}^{-} \rightarrow 2 \mathrm{Cr}^{3+}+7 \mathrm{OH}^{-} \text {(Acidic medium) } \\
& \mathrm{CrO}_{4}^{2-}+3 \mathbf{e}^{-}+4 \mathbf{H}_{\mathbf{2}} \mathbf{O} \rightarrow \mathbf{C r}^{3+}+\mathbf{8} \mathbf{O H}^{-} \text {(Alkaline medium) }
\end{aligned}
$$

Anode reaction:

$$
\mathrm{Fe}_{\mathrm{s}} \rightarrow \mathrm{Fe}^{2+}+2 \mathrm{e}^{-}
$$

In addition to the above-mentioned reactions, the ferrous ions produced at the cathode will facilitate the reduction of $\mathrm{Cr}(\mathrm{VI})$ to $\mathrm{Cr}(\mathrm{III})$ [20]:

$$
\begin{gathered}
\mathrm{Cr}_{2} \mathrm{O}_{7}^{2-}+14 \mathrm{H}^{+}+6 \mathrm{Fe}^{2+} \rightarrow 2 \mathrm{Cr}^{3+}+6 \mathrm{Fe}^{3+}+7 \mathrm{H}_{2} \mathrm{O} \\
\mathrm{CrO}_{4}^{2-}+3 \mathrm{Fe}^{2+}+4 \mathrm{H}_{2} \mathrm{O} \rightarrow \mathrm{Cr}^{3+}+3 \mathrm{Fe}^{3+}+\mathbf{8} \mathbf{O H}^{-} \\
\mathbf{2} \mathbf{H}_{2} \mathbf{O}_{(1)} \rightarrow \mathbf{2} \mathbf{O H}^{-}+\mathbf{H}_{2(\mathrm{~g})}
\end{gathered}
$$

In site reactions:

$$
\begin{aligned}
& \mathrm{Cr}^{3+}+3 \mathrm{OH}^{-} \rightarrow \mathrm{Cr}(\mathrm{OH})_{3(\mathrm{~s})} \\
& \mathrm{Fe}^{3+}+3 \mathrm{OH}^{-} \rightarrow \mathrm{Fe}(\mathrm{OH})_{3(\mathrm{~s})}
\end{aligned}
$$


The $\mathrm{pH}$ of the solution in EC process changes throughout the process, and this eventually affects the final $\mathrm{pH}$ of the solution, which has an immense effect on the removal efficiency [21,22]. For example, if the initial $\mathrm{pH}$ of the solution is acidic (less than 4), the effluent $\mathrm{pH}$ usually increases. On the other hand, it tends to decrease when the initial $\mathrm{pH}$ value is basic (higher than 8) [23,24]. This can be explained by the continuous hydroxyl ion supply at the cathode in Equation (8). In the case of a neutral initial $\mathrm{pH}$, the effluent $\mathrm{pH}$ only changes slightly, to be approximately between 6 and 8 .

\section{Materials and Methods}

\subsection{Tannery Wastewater}

Tannery wastewater samples were collected according to the Standard Method 1060 B [25]. The wastewater was taken from an effluent stream of a leather tanning facility of the White Nile tannery company, Khartoum, Sudan.

\subsection{Wastewater Characterization}

The wastewater was characterized for $\mathrm{pH}$, conductivity, Total Dissolved Solids (TDS), Total Suspended Solids (TSS), Chemical Oxygen Demand (COD), chloride and sulphate. The chromium concentration was also determined using Inductively Coupled Plasma Optical Emission Spectrometry (710 Varian ICP-OES, Agilent Technologies: Santa Clara, CA, USA), and the measurements were carried out in triplicate. The characteristics of the effluent are presented in Table 1. XPS was used to analyze the surface chemical composition of the electrocoagulation sludge [26,27]. The XPS analysis was carried out in an ultra-high vacuum system (Model Ultra OLD XPS by KRATOS, Manchester, UK), equipped with a monochromatic AL Ka radiation source (1486.6 ev) and conducted under an Ultra High Vacuum (UHV) environment at a pressure of $5 \times 10^{-9}$ torr. The instrument was calibrated by C1S to give a reference Binding Energy (BE) of $284.64 \mathrm{ev.}$

Table 1. Characteristics of the tanning wastewater.

\begin{tabular}{ccc}
\hline Parameter & Unit & Value Range \\
\hline $\mathrm{pH}$ & - & $3.4-3.7$ \\
\hline Conductivity & $\mathrm{mS} \mathrm{cm}^{-1}$ & $44-55$ \\
\hline COD & $\mathrm{mg} \mathrm{L}^{-1}$ & $5250-9600$ \\
\hline Total Dissolved Solids & $\mathrm{mg} \mathrm{L}^{-1}$ & $38,200-39,400$ \\
\hline Total Suspended Solids & $\mathrm{mg} \mathrm{L}^{-1}$ & $256-289$ \\
\hline Sulphate & $\mathrm{mg} \mathrm{L}^{-1}$ & $9987-11,527$ \\
\hline Chloride & $\mathrm{mg} \mathrm{L}^{-1}$ & $26,513-31,103$ \\
\hline Total Organic Carbon & $\mathrm{mg} \mathrm{L}^{-1}$ & $2060-2710$ \\
\hline Total Nitrogen & $\mathrm{mg} \mathrm{L}^{-1}$ & $115-136$ \\
\hline Chromium & $\mathrm{mg} \mathrm{L}^{-1}$ & $2705-3800$ \\
\hline
\end{tabular}

\subsection{Experimental Design}

Screening experiments have been conducted to determine the effects of the operational parameters ( $\mathrm{pH}, \mathrm{Cr}$ concentration and current density) on EC efficiency. The data from the screening experiments are used to evaluate the applicable range of these parameters (Table 2), and they are used to deduce an experimental design using Response Surface Methodology (RSM). It is a technique often used to describe the behavior of experimental data by generating a second order model to represent the data. Thereafter, statistical previsions are made to determine the accuracy of the model. The model can be further utilized to optimize and tune the system output to achieve the best possible outcome with that 
specific set of operating parameters [28]. It is designed to give insights into the potential interactions between the operating parameters. This provides a key advantage for Design of Experiment (DOE) over other approaches, as the variables are not varied one at a time while the others are held constant. For a three-factor system (e.g., pH, Cr concentration and current density), a total of 20 experiments are generated to determine the optimum conditions for optimum $\mathrm{Cr}$ removal, taking into consideration the interaction among the factors. Minitab 17.0 is used to analyze the results from these experiments and fit them into a second-order model through a central composite design (CCD). The fitted results will be used to develop a general second-order model as given by the equation below:

$$
Y=\beta_{0}+\sum_{i=1} \beta_{i} X_{i}+\sum_{i=1} \beta_{i i} X_{i}^{2}+\sum_{i=1} \sum_{j=i+1} \beta_{i j} X_{i} X_{j}
$$

where $Y$ is the response function, $\beta_{0}$ the offset term, $\beta_{i}$ the linear effect coefficient, $\beta_{i i}$ the squared effect coefficient, $X_{i}$ the coded value of variable $i, X_{j}$ the coded value of variable $j$ and $\beta_{i j}$ the interaction effect coefficient [29].

Table 2. Range of experiment parameters for central composite design (CCD) runs.

\begin{tabular}{ccc}
\hline Parameter & Unit & Range \\
\hline $\mathrm{pH}$ & - & $2.29-10.7$ \\
\hline Cr concentration & $\mathrm{ppm}$ & $329.55-1170.45$ \\
\hline Current density & $\mathrm{mA} / \mathrm{cm}^{2}$ & $1.2-24.7$ \\
\hline
\end{tabular}

\subsection{Experimental Setup}

The electrocoagulation experiments were conducted using a batch Plexiglas cylindrical reactor $(\mathrm{ID}=15 \mathrm{~cm} ; \mathrm{H}=20 \mathrm{~cm})$. The volume of the treated tannery water in each experiment was $1000 \mathrm{~mL}$. Flat, rectangular sheets of iron metal electrodes were used with dimensions of $60 \mathrm{~mm}(\mathrm{length}) \times$ $50 \mathrm{~mm}$ (width) $\times 2 \mathrm{~mm}$ (thickness) and a total anode surface area of $60 \mathrm{~cm}^{2}$. The metal electrodes were placed in the middle of the reactor and the gap between the anode and cathode was fixed at about $40 \mathrm{~mm}$, and they were connected to a DC power supply (RIGOL DP 811A Programmable DC, RIGOL Technologies: Beijing, China). All experiments were carried out at room temperature $\left(25^{\circ} \mathrm{C}\right)$. The $\mathrm{pH}$ and conductivity of the wastewater sample were measured before the experiments, and the mass of the electrodes was recorded before and after each experiment. The wastewater volume was kept constant at $1000 \mathrm{~mL}$, while varying the main operating parameters $(\mathrm{pH}$, initial $\mathrm{Cr}$ concentration and current density) for each experiment according to RSM. After EC treatment, the treated wastewater was collected, filtered and used for analysis by ICP-OES. The generated sludge was also collected, dried and characterized.

\section{Results and Discussion}

\subsection{RSM Optimization of the Experimental Parameters}

Both the experimental and predicted $\mathrm{Cr}$ removal performance for the 20 experiments are reported in Table 3. The chromium removal ranged from $19 \%$ to $100 \%$.

\subsection{Analysis of Variance and Model Fitting}

Table 4 shows ANOVA for the response of chromium removal at the selected operating parameters. The $\mathrm{P}$ value of the model determines if any given factor is significant or not. A parameter or a model with a $\mathrm{P}$ value $<0.05$ is considered significant. The current density, $\mathrm{pH}$ and initial $\mathrm{Cr}$ concentration are significant factors with $\mathrm{P}$ values $<0.05$. The model equation, in terms of significant factors only, can be described as the following: 


$$
\begin{gathered}
\mathrm{Cr} \%=-141.62+15.06 \mathrm{CD}+37.80 \mathrm{pH}-0.069 \mathrm{Conc}-0.26 \mathrm{CD} \times \mathrm{CD}-1.95 \mathrm{pH} \times \mathrm{pH} \\
-0.84 \mathrm{CD} \times \mathrm{pH}+0.01 \mathrm{pH} \times \mathrm{Conc}
\end{gathered}
$$

\begin{tabular}{|c|c|c|c|c|c|}
\hline \multirow{2}{*}{ Run No. } & \multirow{2}{*}{$\begin{array}{c}\mathrm{CD} \\
\mathrm{mA} / \mathrm{cm}^{2}\end{array}$} & \multirow{2}{*}{$\mathrm{pH}$} & \multirow{2}{*}{$\begin{array}{c}\text { Concentration } \\
\text { ppm }\end{array}$} & \multicolumn{2}{|c|}{ Cr Removal \% } \\
\hline & & & & Experimental & Predicted \\
\hline 1 & 20.00 & 4.00 & 1000.00 & 71.40 & 70.56 \\
\hline 2 & 20.00 & 9.00 & 1000.00 & 99.90 & 99.99 \\
\hline 3 & 13.00 & 6.50 & 750.00 & 98.50 & 95.20 \\
\hline 4 & 13.00 & 6.50 & 1170.45 & 84.60 & 85.90 \\
\hline 5 & 06.00 & 4.00 & 500.00 & 24.50 & 22.76 \\
\hline 6 & 20.00 & 9.00 & 500.00 & 95.00 & 95.62 \\
\hline 7 & 13.00 & 6.50 & 750.00 & 94.80 & 95.20 \\
\hline 8 & 13.00 & 6.50 & 750.00 & 94.60 & 95.20 \\
\hline 9 & 13.00 & 10.70 & 750.00 & 100.00 & 100.30 \\
\hline 10 & 13.00 & 6.50 & 750.00 & 94.60 & 94.70 \\
\hline 11 & 13.00 & 6.50 & 750.00 & 94.50 & 94.70 \\
\hline 12 & 01.22 & 6.50 & 750.00 & 23.30 & 23.12 \\
\hline 13 & 24.77 & 6.50 & 750.00 & 93.00 & 93.06 \\
\hline 14 & 06.00 & 4.00 & 1000.00 & 2.80 & 3.54 \\
\hline 15 & 13.00 & 6.50 & 750.00 & 94.30 & 94.70 \\
\hline 16 & 06.00 & 9.00 & 500.00 & 86.00 & 86.17 \\
\hline 17 & 20.00 & 4.00 & 500.00 & 92.50 & 93.31 \\
\hline 18 & 13.00 & 6.50 & 329.55 & 99.90 & 100.30 \\
\hline 19 & 13.00 & 2.29 & 750.00 & 19.50 & 19.90 \\
\hline 20 & 06.00 & 9.00 & 1000.00 & 90.00 & 91.11 \\
\hline
\end{tabular}

Table 3. CCD experimental design and the measured and predicted responses.

Table 4. ANOVA analysis for Cr removal.

\begin{tabular}{ccccccc}
\hline Source & $\begin{array}{c}\text { Degrees of } \\
\text { Freedom (DF) }\end{array}$ & $\begin{array}{c}\text { Adjusted } \\
\text { Sum Square }\end{array}$ & $\begin{array}{c}\text { Adjusted } \\
\text { Mean Square }\end{array}$ & F-Value & P-Value & Significance \\
\hline Model & 9 & $19,152.5$ & 2128.05 & 0579.51 & 0.000 & Significant \\
\hline Linear & 3 & $12,960.0$ & 4319.99 & 1176.42 & 0.000 & Significant \\
\hline $\mathrm{CD}$ & 1 & 5439.6 & 5439.58 & 1481.31 & 0.000 & Significant \\
\hline $\mathrm{pH}$ & 1 & 7255.6 & 7255.64 & 1975.86 & 0.000 & Significant \\
\hline Conc & 1 & 0264.8 & 264.76 & 72.10 & 0.000 & Significant \\
\hline Square & 3 & 4121.6 & 1373.88 & 374.14 & 0.000 & Significant \\
\hline $\mathrm{CD} \times \mathrm{CD}$ & 1 & 2353.5 & 353.45 & 640.89 & 0.000 & Significant \\
\hline $\mathrm{pH} \times \mathrm{pH}$ & 1 & 2137.3 & 2137.28 & 582.02 & 0.000 & Significant \\
\hline Conc $\times$ Conc & 1 & 6.8 & 6.81 & 1.86 & 0.203 & Not significant \\
\hline $2-$ Way Interaction & 3 & 2070.9 & 690.29 & 187.98 & 0.000 & Significant \\
\hline $\mathrm{CD} \times \mathrm{pH}$ & 1 & 1740.5 & 1740.50 & 473.97 & 0.000 & Significant \\
\hline $\mathrm{CD} \times$ Conc & 1 & 0.1 & 0.13 & 0.03 & 0.857 & Not significant \\
\hline $\mathrm{pH} \times$ Conc & 1 & 330.2 & 330.25 & 89.93 & 0.000 & Significant \\
\hline Error & 10 & 36.7 & 3.67 & & & \\
\hline Lack-of-Fit & 5 & 23.7 & 0004.73 & 1.81 & 0.265 & Not significant \\
\hline Pure Error & 5 & 13.1 & 0002.61 & & & \\
\hline & & & & &
\end{tabular}




\subsection{Effects of Experimental Parameters on the Percentage Cr Removal}

The RSM predicted data are plotted in 3D to give a graphical representation of the regression equation, which is used to predict the relationship between the responses and the variables affecting the removal efficiency as shown in Figure 1. It shows the relationship between the independent and dependent variables and represents the response surface generated by the model. The plot shows how chromium removal relates to the three continuous variables $\mathrm{CD}, \mathrm{pH}$ and initial chromium concentration. Figure 1a shows that the optimum chromium removal happens at a neutral $\mathrm{pH}(6-8)$ and initial $\mathrm{Cr}$ concentration of $1000 \mathrm{mg} / \mathrm{L}$. This can be attributed to the fact that iron ions are converted to iron hydroxide at a $\mathrm{pH}$ of 6.5 as indicated in Figure 2. Furthermore, the formed hydroxide ions (at the cathode) lead to the precipitation of $\mathrm{Cr}(\mathrm{III})$ ions as insoluble $\mathrm{Cr}(\mathrm{OH}) 3$ [17]. In addition, as mentioned in the mechanism section, the $\mathrm{pH}$ is an essential factor in determining the process performance. For example, the rate of hexavalent chromium removal, under acidic conditions, decreases with increasing $\mathrm{pH}$. Nonetheless, at $\mathrm{pH}$ values greater than 4.0, the opposite effect is induced (it increases) [30-33]. This can be explained by the increase in ferrous oxide concentration in the solution at $\mathrm{pH}$ values over 4 [28]. As for the case of current density, Figure $1 \mathrm{~b}$ illustrates that an optimum $\mathrm{Cr}$ removal occurs at a CD of $15 \mathrm{~mA} / \mathrm{cm}^{2}$ and a high initial $\mathrm{Cr}$ concentration. An optimum removal takes place when the $\mathrm{pH}$ is around 7 and the $\mathrm{CD}$ is $13 \mathrm{~mA} / \mathrm{cm}^{2}$, as illustrated in Figure 1c.

(a)

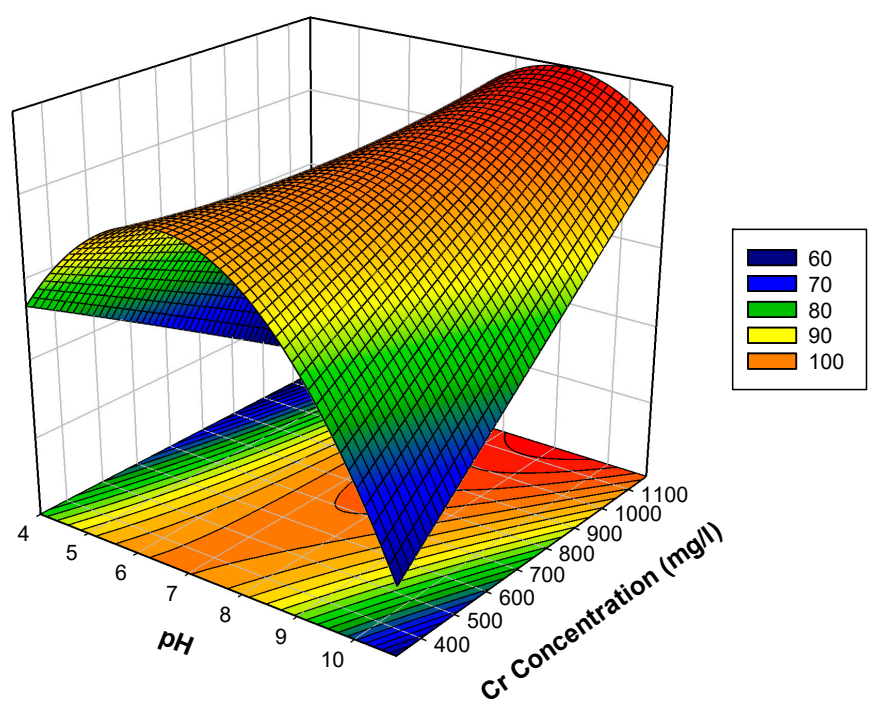

(b)

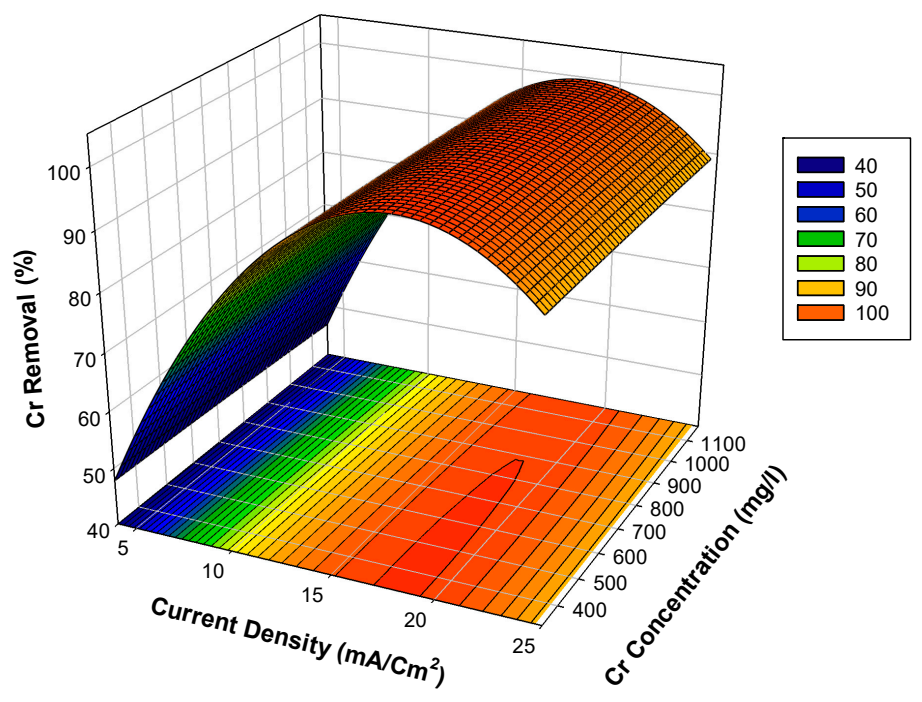

Figure 1. Cont. 
(c)

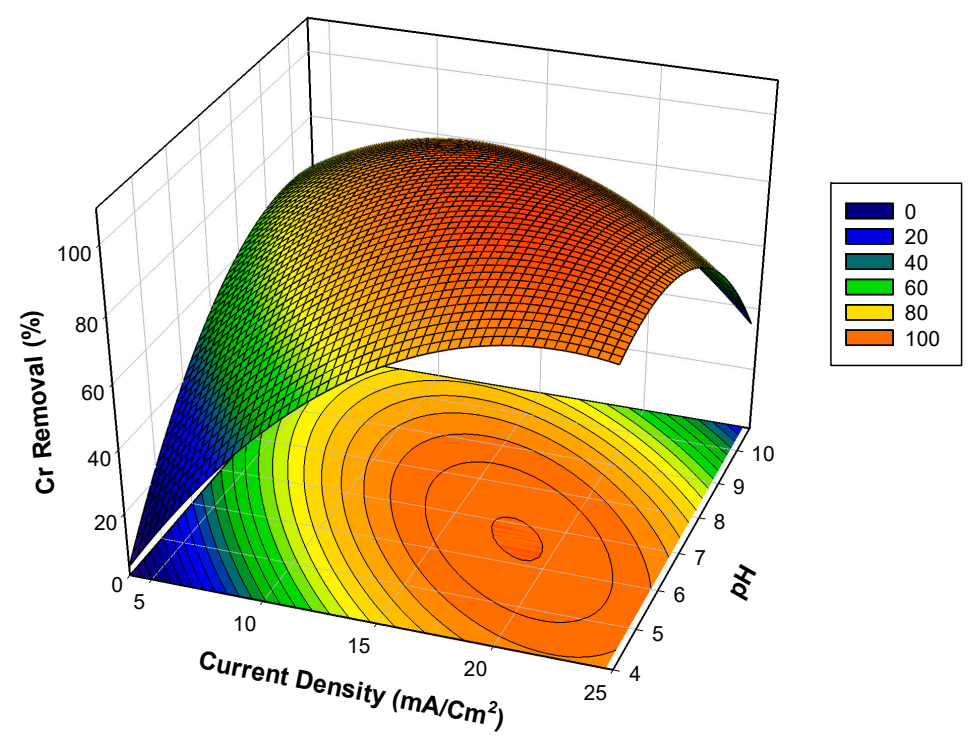

Figure 1. Contour and $3 \mathrm{D}$ response surface showing the effect of the experimental parameters on $\mathrm{Cr}$ removal \%. (a) Initial $\mathrm{Cr}$ concentration and $\mathrm{pH}$; (b) Initial $\mathrm{Cr}$ concentration and current density; (c) Current density and $\mathrm{pH}$.

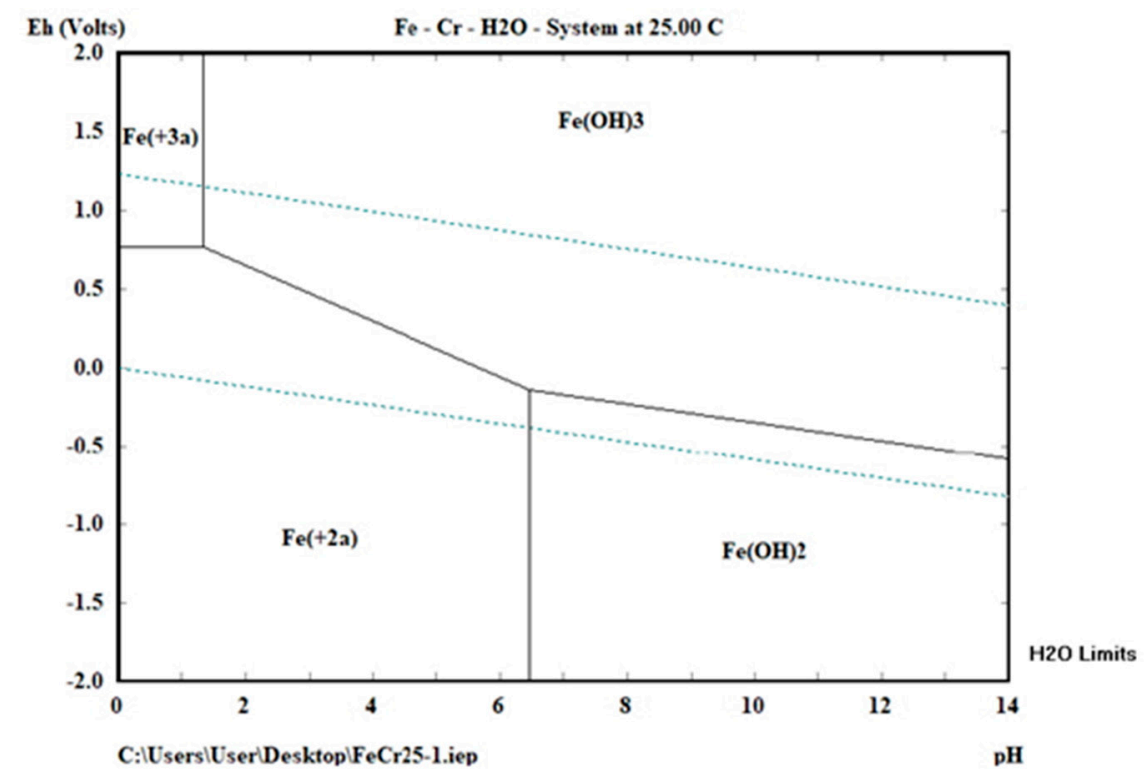

Figure 2. Phase diagram of chromium and iron system at $25^{\circ} \mathrm{C}$.

\subsection{Kinetic Modeling}

First and second order models were studied at a current density of $12 \mathrm{~mA} / \mathrm{cm}^{2}$ throughout the duration of the experiments (30 $\mathrm{min})$.

The first order model was calculated according the equation below:

$$
\log \left(q_{e}-q_{t}\right)=\log \left(q_{e}\right)-k_{t} t / 2.203
$$

where $q_{e}$ and $q_{t}$ are the adsorption capacities $(\mathrm{mg} / \mathrm{g}$ ) at equilibrium time and $t$ time (min), respectively.

The second order model was calculated according the equation below:

$$
\frac{t}{q_{t}}=\frac{1}{k_{t} q_{e}^{2}}+\frac{t}{q_{e}}
$$


where $q_{e}$ and $q_{t}$ are the adsorption capacities $(\mathrm{mg} / \mathrm{g})$ at equilibrium time and $t$ time $(\mathrm{min})$, respectively.

It is important to note that the EC process involves different mechanisms including floatation, coagulation and adsorption. Fitting the data into first and/or second order adsorption kinetics models neglects the contribution of other mechanisms and only takes into consideration adsorption. This is not an inclusive approach for modeling the EC process; nonetheless, this approach has been reported in the literature several times [34,35]. The experimental data were fitted into first and second order kinetic models. The first order model gave a poor fit of the experimental results (Figure 3) compared to the pseudo-second order model (Figure 4). Two trends can be observed from the two figures. At the beginning of the EC process (5-15 min), the rate fits the second order model, while towards the end of the process (15-30 $\mathrm{min}$ ), the data fit the first order one. Hence, the removal of $\mathrm{Cr}$ is highly dependent on its initial concentration (second order model), and this dependency decreases with time towards the end of the experiment (first order model). However, the model fitting does not represent the actual mechanism and may involve inaccuracies since, as stated above, adsorption is not the only mechanism that takes place during the EC process. Figure 5 shows chromium removal over time for different concentrations. It illustrates that high removal values are achieved if the initial concentration of $\mathrm{Cr}$ is low. This is expected, since higher $\mathrm{Cr}$ concentrations will decrease the removal efficiency.

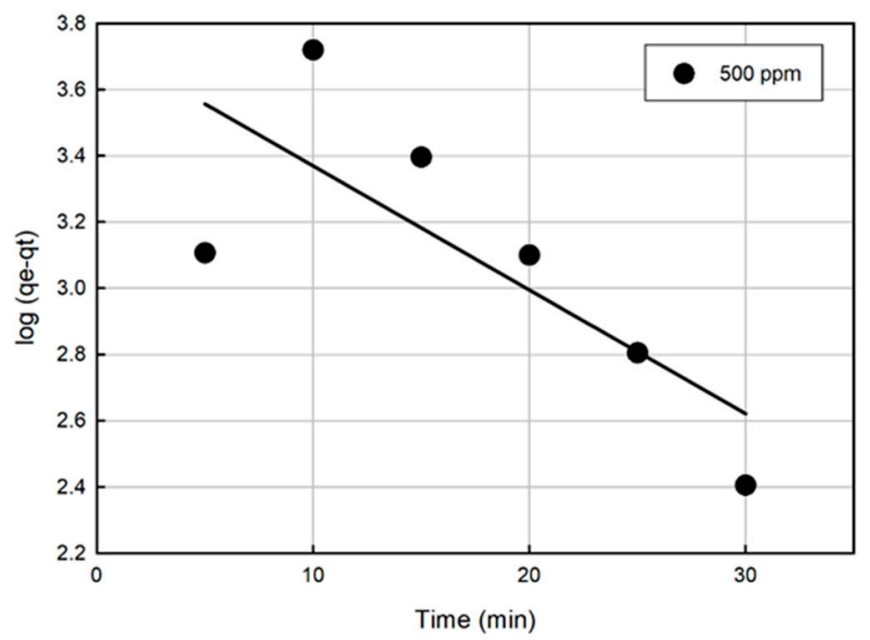

Figure 3. First order model for a chromium concentration of $500 \mathrm{ppm}$, current density of $13 \mathrm{~mA} / \mathrm{cm}^{2}$ and $\mathrm{pH}$ of 7.

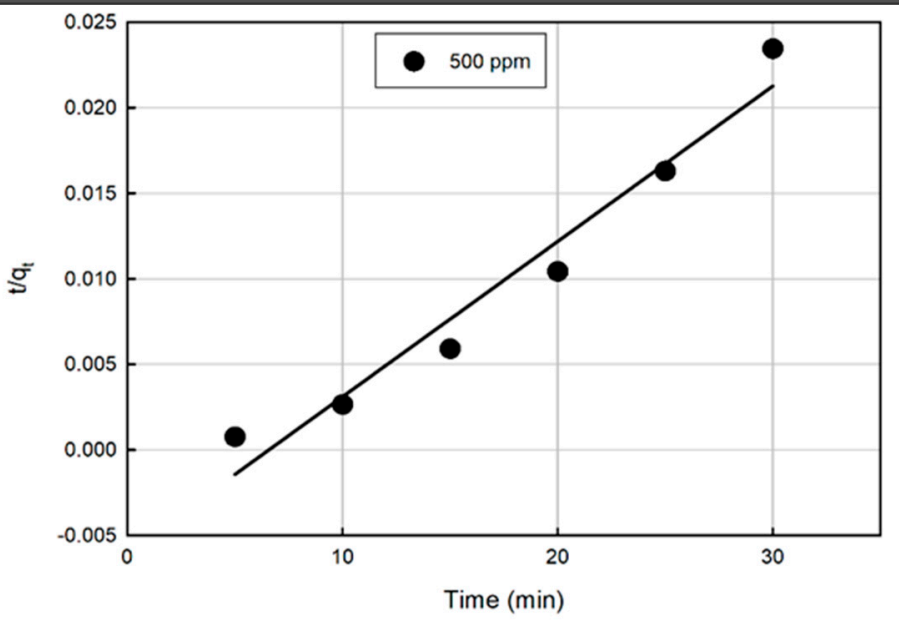

Figure 4. Second order model for a chromium concentration of $500 \mathrm{ppm}$, current density of $13 \mathrm{~mA} / \mathrm{cm}^{2}$ and $\mathrm{pH}$ of 7. 


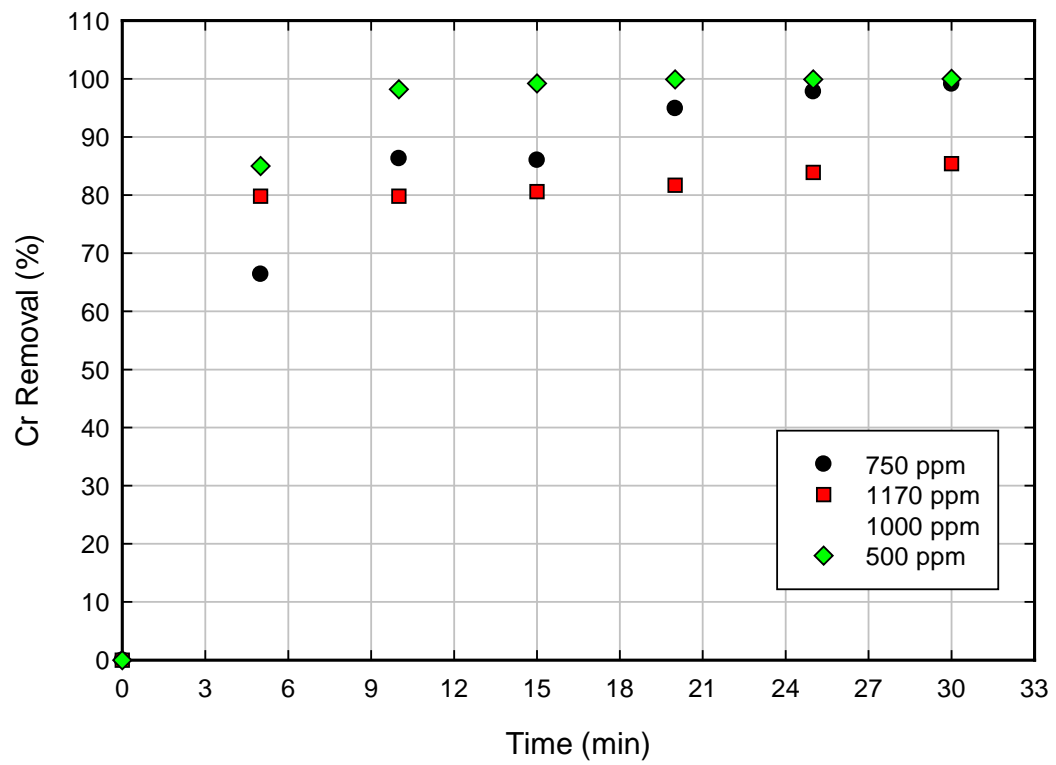

Figure 5. Effect of electrolysis time on Cr removal \%.

\subsection{X-ray Photoelectron Spectroscopy (XPS)}

The full survey of XPS showed the presence of C1S, O 1S, Cr 2P, S 2P, Cl 2P, Na 1S in surface chemical composition results as shown in Table 5. In addition, Figure 6 shows the spectral lines for the EC sludge samples at two concentrations (500 and $1000 \mathrm{ppm}$ ) compared to sludge from an evaporated tannery water sample before treatment.

For the low chromium concentration experiment (500 ppm), the $\mathrm{CD}\left(20 \mathrm{~mA} / \mathrm{cm}^{2-}\right)$ was double that for the high chromium concentration (1000 ppm), which in turn resulted in generating more iron $(10.49 \%)$ in the EC sludge, as indicated in Table 5. At this high $\mathrm{pH}$ of 9, chromium removal increases with an increase in the initial concentration (Figure 1a). However, since the CD is lower for the 1000 ppm experiment, the obtained chromium removal was lower $(90 \%)$ than that for the low concentration (95\%). It is worth mentioning here that the low current density limits the amount of dissolved iron and, hence, reduces the chromium removal.

Table 5. XPS atomic concentration analysis at two chromium concentrations.

\begin{tabular}{|c|c|c|c|c|}
\hline \multirow{2}{*}{$\begin{array}{c}\begin{array}{c}\text { Initial Cr } \\
\text { Concentration }\end{array} \\
\text { Peak }\end{array}$} & \multicolumn{2}{|c|}{$\begin{array}{c}500 \mathrm{ppm} \\
\left(\mathrm{CD}: 20 \mathrm{~mA} / \mathrm{cm}^{2} \text { and } \mathrm{pH}: 9\right)\end{array}$} & \multicolumn{2}{|c|}{$\begin{array}{c}1000 \mathrm{ppm} \\
\left(\mathrm{CD}: 6 \mathrm{~mA} / \mathrm{cm}^{2} \text { and } \mathrm{pH}: 9\right)\end{array}$} \\
\hline & Position BE (ev) & Atomic Conc. \% & Position BE (ev) & Atomic Conc. \% \\
\hline C $1 S$ & 281.00 & 30.02 & 281.00 & 33.13 \\
\hline O 1S & 527.00 & 44.61 & 527.00 & 45.64 \\
\hline $\mathrm{Cr} 2 \mathrm{P}$ & 573.00 & 5.63 & 573.00 & 7.02 \\
\hline$S 2 S$ & 165.00 & 1.42 & 165.00 & 1.09 \\
\hline $\mathrm{Cl} 2 \mathrm{~S}$ & 196.00 & 3.51 & 196.00 & 3.97 \\
\hline $\mathrm{Na} 1 \mathrm{~S}$ & 1068.00 & 4.32 & 1067.00 & 5.59 \\
\hline Fe $2 S$ & 708.00 & 10.49 & 707.00 & 3.56 \\
\hline
\end{tabular}




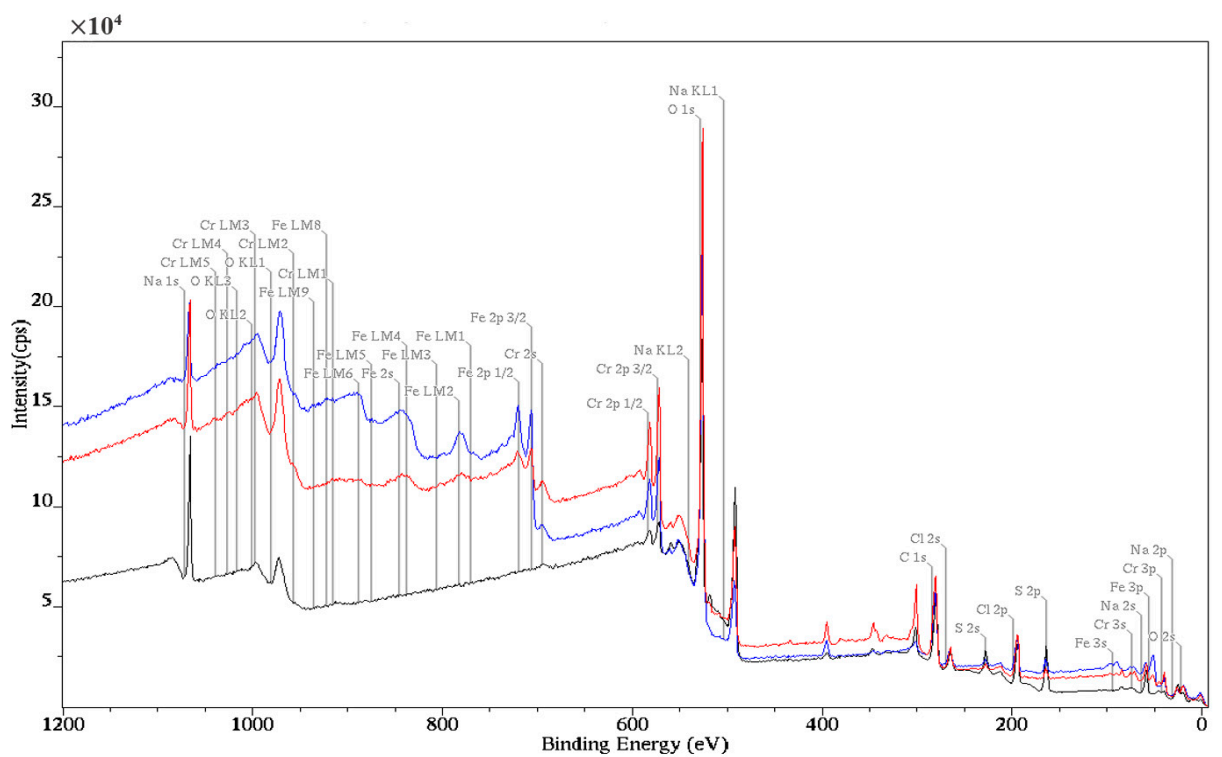

Figure 6. Full survey X-ray photoelectron spectroscopy of evaporated sludge after electrocoagulation.

The high-resolution XPS spectra of $\mathrm{Cr} 2 \mathrm{p}$ in $1000 \mathrm{ppm}$ sample were de-convoluted into four peaks; two peaks located at $577.06 \mathrm{eV}$ for $\mathrm{Cr} 2 \mathrm{p}_{3 / 2}$ and $586.8 \mathrm{eV}$ for $\mathrm{Cr} 2 \mathrm{p}_{1 / 2}$ assigned to $\mathrm{Cr}-\mathrm{O}$ along with two peaks at binding energies of 579.66 for $\mathrm{Cr} 2 \mathrm{p}_{3 / 2}$ and $589.7 \mathrm{eV}$ for $\mathrm{Cr} 2 \mathrm{p}_{1 / 2}$ and assigned $\mathrm{Cr}-\mathrm{OH}$ (Figure 7). The distributions of the chromium oxides and chromium hydroxides for the concentrations of $500 \mathrm{ppm}$ were determined to be $75.98 \%$ and $24.02 \%$, respectively. However, the distributions for the oxides and hydroxides were determined to be $79.28 \%$ and $20.72 \%$ for the EC sludge at $1000 \mathrm{ppm}$ as shown in Table 6.

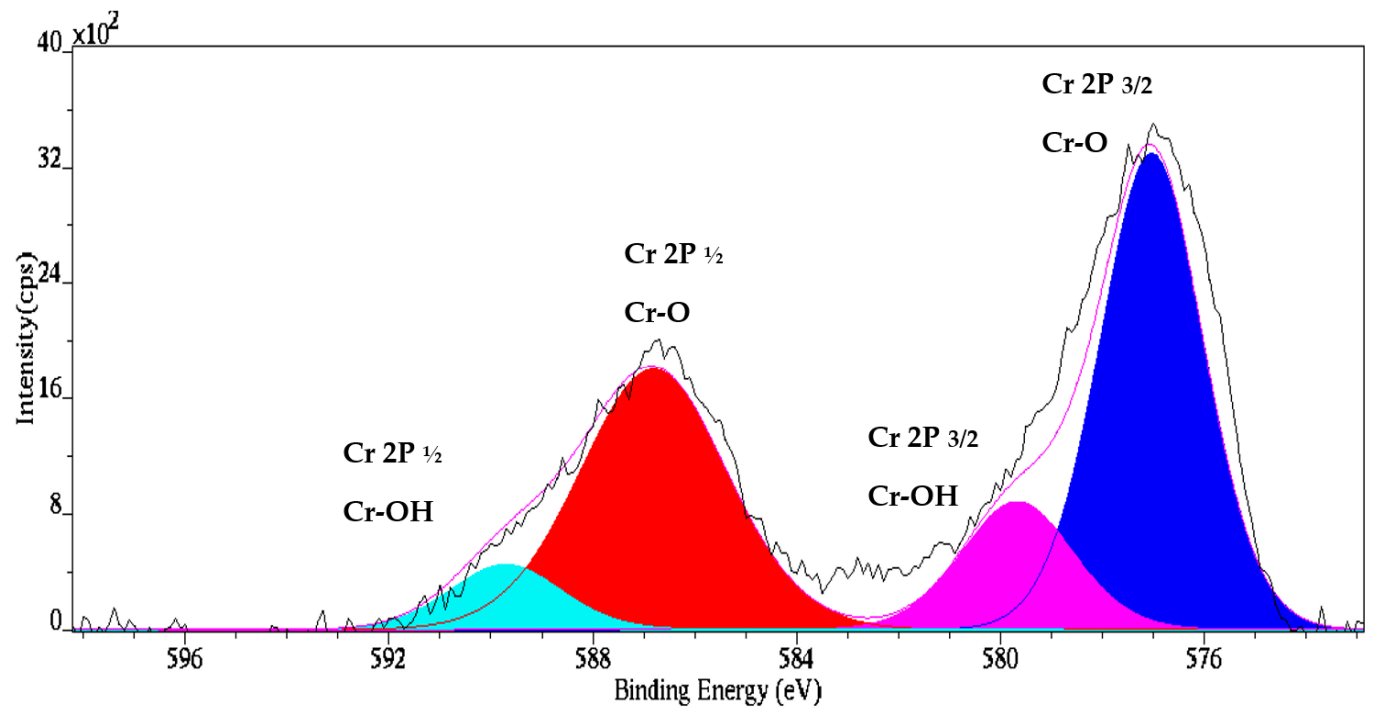

Figure 7. High-resolution XPS spectra of $\mathrm{Cr} 2 \mathrm{p}$ in the 1000 ppm sludge sample.

Table 6. Cr $2 \mathrm{p}$ ratio for $\mathrm{Cr}-\mathrm{O}$ and $\mathrm{Cr}-\mathrm{OH}$.

\begin{tabular}{ccccc}
\hline & 500 ppm & & \multicolumn{2}{c}{ 1000 ppm } \\
\hline Peak & Position BE (ev) & $\begin{array}{c}\text { Atomic } \\
\text { Concentration \% }\end{array}$ & Position BE (ev) & $\begin{array}{c}\text { Atomic } \\
\text { Concentration \% }\end{array}$ \\
\hline Cr 2P Cr-O & 586.417 & 75.98 & 586.816 & 79.28 \\
\hline Cr 2 P Cr-OH & 589.568 & 24.02 & 589.697 & 20.72 \\
\hline
\end{tabular}




\section{Conclusions}

Electrocoagulation proved to be an effective treatment technology for the removal of chromium from tannery wastewater. Tannery wastewater samples were treated using an EC cell with iron electrodes under different operating conditions. Response Surface Methodology was used to evaluate the effect of each parameter on the removal efficiency. The experimental results showed that the performance of EC in chromium removal is largely affected by the initial chromium concentration, current density and solution $\mathrm{pH}$. The results showed that chromium removal can reach up to $100 \%$ at a $\mathrm{pH}$ of 7 and a current density of $13 \mathrm{~mA} / \mathrm{cm}^{2}$. Furthermore, the sludge generated from the EC process was analyzed by XPS to determine the surface composition. The distributions for chromium oxides and hydroxides were determined to be $79.28 \%$ and $20.72 \%$, respectively. The results indicated that the surface had an increase in chromium hydroxide content as compared to before the treatment, as a result of the EC process. The resulting chromium hydroxide can be recycled back to be used as a raw material.

Author Contributions: Conceptualization, N.M.G., M.H.E.-N. and A.E.A.; methodology, N.M.G. \& M.H.E.-N.; software, M.H.I.; validation, N.M.G.; formal analysis, N.M.G. and M.H.E.-N.; investigation, N.M.G., M.H.E.-N. and M.H.I.; resources, N.M.G., M.H.E.-N. and A.E.A.; data curation, N.M.G., M.H.E.-N. and M.H.I.; writing-original draft preparation, N.M.G.; writing-review and editing, N.M.G., M.H.E.-N. and M.H.I.; supervision, M.H.E.-N. and A.E.A.; project administration, M.H.E.-N.; All authors have read and agreed to the published version of the manuscript.

Funding: This research received no external funding.

Acknowledgments: The authors are grateful to the staff of the Gas Processing Center (GPC) for their help with the experimental work, especially Ahmed Soliman and Dan Cortes. They would also like to thank the Environmental Research Centre, the Chemical Engineering Department, and the Central Laboratory Unit at Qatar University for their support.

Conflicts of Interest: The authors declare no conflict of interest.

\section{References}

1. Anderson, R.A. Nutritional role of chromium. Sci. Total Environ. 1981, 17, 13-29. [CrossRef]

2. OSHA. Fact Sheet Health Effects of Hexavalent Chromium Hexavalent; OSHA: Washington, DC, USA, 2006.

3. Saha, R.; Nandi, R.; Saha, B. Sources and toxicity of hexavalent chromium. J. Coord. Chem. 2011, 64, 1782-1806. [CrossRef]

4. Megharaj, M.; Avudainayagam, S.; Naidu, R. Toxicity of hexavalent chromium and its reduction by bacteria isolated from soil contaminated with tannery waste. Curr. Microbiol. 2003, 47, 51-54. [CrossRef]

5. Kleber, R.J.; Helz, G.R. Indirect Photoreduction of Aqueous Chromium(VI). Environ. Sci. Technol. 1992, $26,307-312$.

6. Saha, B.; Orvig, C. Biosorbents for hexavalent chromium elimination from industrial and municipal effluents. Coord. Chem. Rev. 2010, 254, 2959-2972. [CrossRef]

7. Electronic Code of Federal Regulations, Environmental Protection Agency. Protection of Environment, Part 425-Leather Tanning and Finishing Point Source Category. Available online: https://www.govinfo.gov/ app/details/CFR-2012-title40-vol31/CFR-2012-title40-vol31-part425 (accessed on 2 May 2020).

8. Fu, F.; Wang, Q. Removal of heavy metal ions from wastewaters: A review. J. Environ. Manag. 2011, 92, 407-418. [CrossRef]

9. Moussa, D.T.; El-Naas, M.H.; Nasser, M.; Al-Marri, M.J. A comprehensive review of electrocoagulation for water treatment: Potentials and challenges. J. Environ. Manag. 2017, 186, 24-41. [CrossRef]

10. Sayali, .D.A.; Chavan, F.I.; Hussain, M. Electrocoagulation of Waste Water by Using Iron and Aluminium. In Proceedings of the International Conference Proceeding ICGTETM, Jalgaon, India, 4-6 January 2016; pp. $15-21$.

11. Song, Z.; Williams, C.J.; Edyvean, R.G.J. Sedimentation of tannery wastewater. Water Res. 2000, 34, 2171-2176. [CrossRef]

12. Mwinyihija, M.; Meharg, A.; Dawson, J.; Strachan, N.J.C.; Killham, K. An ecotoxicological approach to assessing the impact of tanning industry effluent on river health. Arch. Environ. Contam. Toxicol. 2006, 50, 316-324. [CrossRef]

13. Körbahti, B.K.; Tanyolaç, A. Electrochemical treatment of simulated industrial paint wastewater in a continuous tubular reactor. Chem. Eng. J. 2009, 148, 444-451. [CrossRef] 
14. Moisés, T.-P.; Patricia, B.-H.; Barrera-Díaz, C.E.; Gabriela, R.-M.; Natividad-Rangel, R. Treatment of industrial effluents by a continuous system: Electrocoagulation-Activated sludge. Bioresour. Technol. 2010, 101, 7761-7766. [CrossRef]

15. Hamdan, S.S.; El-Naas, M.H. An electrocoagulation column (ECC) for groundwater purification. J. Water Process Eng. 2014, 4, 25-30. [CrossRef]

16. Hamdan, S.S.; El-Naas, M.H. Characterization of the removal of Chromium(VI) from groundwater by electrocoagulation. J. Ind. Eng. Chem. 2014, 20, 2775-2781. [CrossRef]

17. Un, U.T.; Onpeker, S.E.; Ozel, E. The treatment of chromium containing wastewater using electrocoagulation and the production of ceramic pigments from the resulting sludge. J. Environ. Manag. 2017, 200, 196-203.

18. Golder, A.K.; Samanta, A.N.; Ray, S. Removal of trivalent chromium by electrocoagulation. Sep. Purif. Technol. 2007, 53, 33-41. [CrossRef]

19. Akbal, F.; Camc1, S. Copper, chromium and nickel removal from metal plating wastewater by electrocoagulation. Desalination 2011, 269, 214-222. [CrossRef]

20. Mouedhen, G.; Feki, M.; de Petris-Wery, M.; Ayedi, H.F. Electrochemical removal of Cr(VI) from aqueous media using iron and aluminum as electrode materials: Towards a better understanding of the involved phenomena. J. Hazard. Mater. 2009, 168, 983-991. [CrossRef]

21. Daneshvar, N.; Oladegaragoze, A.; Djafarzadeh, N. Decolorization of basic dye solutions by electrocoagulation: An investigation of the effect of operational parameters. J. Hazard. Mater. 2006, 129, 116-122. [CrossRef]

22. Yıldız, Y.Ş.; Koparal, A.S.; Keskinler, B. Effect of initial pH and supporting electrolyte on the treatment of water containing high concentration of humic substances by electrocoagulation. Chem. Eng. J. 2008, 138, 63-72. [CrossRef]

23. Lyklema, H. 1-Introduction to Colloid Science. In Particulate Colloids 4; Lyklema, J., Ed.; Academic Press: Cambridge, MA, USA, 2005; pp. 1-16.

24. Rebhun, M.; Lurie, M. Control of Organic Matter by Coagulation and Floc Separation. Water Sci. Technol. 1993, 27, 1-20. [CrossRef]

25. American Public Health Association. Standard Methods for the Examination of Water and Wastewater, Part 1000; American Public Health Association: Washington, DC, USA, 1999.

26. Kuznetsov, M.V.; Volkov, V.L.; Zhakharova, G.S.; Gubanov, V.A. XPS study of catalytic compounds H2V12xMexO31- $\delta$ nH2O (Me: Mo, Cr). J. Electron Spectros. Relat. Phenomena 1994, 68, 579-588. [CrossRef]

27. Sleigh, C.; Pijpers, A.P.; Jaspers, A.; Coussens, B.; Meier, R.J. On the determination of atomic charge via ESCA including application to organometallics. J. Electron Spectros. Relat. Phenomena 1996, 77, 41-57. [CrossRef]

28. Bezerra, M.A.; Santelli, R.E.; Oliveira, E.P.; Villar, L.S.; Escaleira, L.A. Response surface methodology (RSM) as a tool for optimization in analytical chemistry. Talanta 2008, 76, 965-977. [CrossRef]

29. El-Naas, M.H.; Mohammad, A.F.; Suleiman, M.I.; Al-Musharfy, M.; Al-Marzouqi, A.H. Statistical Analysis and Optimization of a Process for $\mathrm{CO}_{2}$ capture. World Acad. Sci. Eng. Technol. Int. J. Chem. Mol. Eng. 2016, 10, $397-404$.

30. Sedlak, D.L.; Chan, P.G. Reduction of hexavalent chromium by ferrous iron. Geochim. Cosmochim. Acta 1997, 61, 2185-2192. [CrossRef]

31. Schlautman, M.A.; Han, I. Effects of $\mathrm{pH}$ and dissolved oxygen on the reduction of hexavalent chromium by dissolved ferrous iron in poorly buffered aqueous systems. Water Res. 2001, 35, 1534-1546. [CrossRef]

32. Pettine, M.; D'Ottone, L.; Campanella, L.; Millero, F.J.; Passino, R. The reduction of chromium (VI) by iron (II) in aqueous solutions. Geochim. Cosmochim. Acta 1998, 62, 1509-1519. [CrossRef]

33. Buerge, I.J.; Hug, S.J. Kinetics and pH dependence of chromium(VI) reduction by iron(II). Environ. Sci. Technol. 1997, 31, 1426-1432. [CrossRef]

34. Yoosefian, M.; Ahmadzadeh, S.; Aghasi, M.; Dolatabadi, M. Optimization of electrocoagulation process for efficient removal of ciprofloxacin antibiotic using iron electrode; kinetic and isotherm studies of adsorption. J. Mol. Liq. 2017, 225, 544-553. [CrossRef]

35. El-Shazly, A.H.; Al-Zahrani, A.A.; Alhamed, Y.A. Kinetics and performance analysis of batch electrocoagulation unit used for the removal of a mixture of phosphate and nitrate ions from industrial effluents. Int. J. Electrochem. Sci. 2013, 8, 3176-3185.

(C) 2020 by the authors. Licensee MDPI, Basel, Switzerland. This article is an open access article distributed under the terms and conditions of the Creative Commons Attribution (CC BY) license (http://creativecommons.org/licenses/by/4.0/). 